\title{
RAMAN SPECTRA OF SINGLE CRYSTALS OF ZINC AND LITHIUM ACETATES DIHYDRATES
}

\author{
By V. Ananthanarayanan \\ (Department of Physics, Indian Institute of Science, Bangalore-12) \\ Received September 24, 1962 \\ (Communicated by Professor R. S. Krishnan, P.A.Sc.)
}

\section{INTRODUCTION}

THE Raman spectra of aqueous solution of the acetate ion and the infra-red spectra of solid metal acetate have been studied by many workers and reliable assignment of the fundamental frequencies of the acetate ion have been made (Ito and Bernstein, 1956). In a communication which appeared in these Proceedings, Padmanabhan (1953) reported the Raman spectra of crystalline barium, sodium and magnesium acetates. The Raman spectra of crystal powders of many acetates including lithium and zinc acetates were recorded by Theimer and Theimer (1950). They have reported only the $\mathrm{C}-\mathrm{C}$ and C-O stretching frequencies in these cases.

The crystal structures of zinc acetate dihydrate and lithium acetate dihydrate have been recently solved (Van Niekerk, Schoening and Talbot, 1953; Amirthalingam and Padmanabhan, 1958). These two acetates are easily crystallised from aqueous solutions and it was felt desirable to investigate their spectra in single crystal form. Being transparent to ultra-violet, their Raman spectra were recorded using $\lambda 2537$ excitation. Interesting results are obtained which are presented here.

\section{EXPERIMENTAL Details}

Single crystals of zinc acetate dihydrate and lithium acetate dihydrate were grown from aqueous solutions of the pure substances by the method of slow evaporation. The biggest crystals of these two substances measured respectively $10 \times 10 \times 3 \mathrm{~mm}$. and $20 \times 20 \times 5 \mathrm{~mm}$. The crystals were free from inclusions. Employing a medium quartz spectrograph and a slit width of $0.025 \mathrm{~mm}$. fairly intense photographs were obtained with exposures of the order of six hours.

\section{REsUlts}

Enlarged photographs of the Raman spectra of zinc and lithium acetates dihydrates are reproduced in Figs. 1 and 2 on PlatesVI and VII. Their respective 188 
microphotometer records are also included. The observed frequency shifts in wave-numbers have been marked in figures. They have also been listed in Table I. The figures given in brackets represent the relative intensities of the Raman lines estimated visually. For the sake of comparison the frequencies observed in the spectra of magnesium acetate tetrahydrate, sodium and barium acetates trihydrates by Padmanabhan (1953) are also included in Table I. In column 6 are given the frequencies of the free acetate

TABLE I

\begin{tabular}{|c|c|c|c|c|c|c|}
\hline \multicolumn{3}{|c|}{ Padmanabhan } & \multicolumn{2}{|c|}{ Author } & \multirow{2}{*}{ 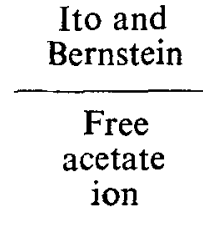 } & \multirow[b]{2}{*}{ Assignment } \\
\hline $\begin{array}{l}\text { Sodium } \\
\text { acetate } \\
\text { tri- } \\
\text { hydrate }\end{array}$ & $\begin{array}{l}\text { Magnesium } \\
\text { acetate } \\
\text { tetra- } \\
\text { hydrate }\end{array}$ & $\begin{array}{l}\text { Barium } \\
\text { acetate } \\
\text { tri- } \\
\text { hydrate }\end{array}$ & $\begin{array}{l}\text { Lithium } \\
\text { acetate } \\
\text { di- } \\
\text { hydrate }\end{array}$ & $\begin{array}{l}\text { Zinc } \\
\text { acetate } \\
\text { di- } \\
\text { hydrate }\end{array}$ & & \\
\hline $\begin{array}{r}46 \\
60 \\
81 \\
109 \\
126\end{array}$ & $\begin{array}{r}52 \\
61 \\
79 \\
\\
114 \\
140 \\
169 \\
169 \\
196 \\
218 \\
\\
254\end{array}$ & $\begin{array}{l}102 \\
130 \\
142\end{array}$ & $\begin{array}{l}65(8) \\
101(15) \\
129(1) \\
147(1) \\
169(2) \\
212(4) \\
237(1) \\
288(f)\end{array}$ & $\begin{array}{c}25(5) \\
50(f) \\
67(10) \\
80(12) \\
91(12) \\
109(12) \\
158(f) \\
230(4) \\
266(8) \\
* 310(-) \\
* 420(--)\end{array}$ & \multicolumn{2}{|c|}{$\begin{array}{l}\text { Lattice frequencies, hydrogen bond } \\
\text { vibrations and internal frequencies } \\
\text { of the arrangement of water } \\
\text { molecules and oxygens around } \\
\text { the metal ions }\end{array}$} \\
\hline 480 & 538 & 540 & $\begin{array}{l}427(-) \\
456(\mathrm{f})\end{array}$ & $\begin{array}{l}476(1) \\
509(f)\end{array}$ & 471 (f) & $\begin{array}{l}2 \times 212 \\
v_{11}\left(b_{1}\right) \text { COO } \\
\text { rocking (in plane) } \\
266+230 \\
v_{15}\left(b_{2}\right) \text { COO rocking } \\
\text { (out of plane) }\end{array}$ \\
\hline
\end{tabular}


TABLE I (Contd.)

\begin{tabular}{|c|c|c|c|c|c|c|}
\hline \multicolumn{3}{|c|}{ Padmanabhan } & \multicolumn{2}{|c|}{ Author } & \multirow{2}{*}{$\begin{array}{c}\begin{array}{c}\text { Ito and } \\
\text { Bernstein }\end{array} \\
\begin{array}{c}\text { Free } \\
\text { acetate } \\
\text { ion }\end{array}\end{array}$} & \multirow[b]{2}{*}{ Assignment } \\
\hline $\begin{array}{l}\text { Sodium } \\
\text { acetate } \\
\text { trihydrate }\end{array}$ & $\begin{array}{l}\text { Magnesium } \\
\text { acetate } \\
\text { tetrahydrate }\end{array}$ & $\begin{array}{l}\text { Barium } \\
\text { acetate } \\
\text { trihydrate }\end{array}$ & $\begin{array}{l}\text { Lithium } \\
\text { acetate } \\
\text { dihydrate }\end{array}$ & $\begin{array}{c}\text { Zinc } \\
\text { acetate } \\
\text { dihydrate }\end{array}$ & & \\
\hline & 668 & 656 & $670(8)$ & $695(2)$ & $650(3)$ & $\begin{array}{r}\nu_{5}\left(a_{1}\right) \mathrm{COO} \\
\text { deformation }\end{array}$ \\
\hline \multirow[t]{5}{*}{910} & $\begin{array}{l}920 \\
930\end{array}$ & $\begin{array}{l}909 \\
918\end{array}$ & $940(20)$ & $954(20)$ & $926(5)$ & $\begin{array}{c}\nu_{4}\left(a_{1}\right) \mathrm{C}-\mathrm{C} \\
\text { stretching }\end{array}$ \\
\hline & & & & & $1020(f)$ & $\begin{array}{l}\nu_{10}\left(b_{1}\right) \mathrm{CH}_{3} \\
\text { rocking }\end{array}$ \\
\hline & & & & $1062(\mathrm{f})$ & $1052(?)$ & $\begin{array}{l}v_{14}\left(b_{2}\right) \underset{\mathrm{C}}{\mathrm{C}} \mathrm{CH}_{8} \\
\text { rocking }\end{array}$ \\
\hline & & & $1267(f)$ & $1248(f)$ & & $\begin{array}{l}\nu_{2}-101 \\
\nu_{2}-109\end{array}$ \\
\hline & & & & 1311 (f) & & $3223-2 v_{u}$ \\
\hline 1350 & 1350 & 1344 & $1356(10)$ & $1360(4)$ & $1344(4)$ & $\begin{array}{r}\nu_{2}\left(a_{1}\right) \mathrm{CH}_{3} \\
\text { deformation }\end{array}$ \\
\hline \multirow[t]{7}{*}{1416} & 1429 & 1434 & & & $1413(8)$ & $\begin{array}{r}v_{3}\left(a_{1}\right) \underset{\text { stretching }}{\mathrm{C}-\mathrm{O}} \\
\text { stching }\end{array}$ \\
\hline & & & $1445(15)$ & $1456(15)$ & & $\nu_{3}$ and $\nu_{13}$ \\
\hline & & & & & $1429(1)$ & $\begin{array}{r}v_{9}\left(b_{1}\right) \mathrm{CH}_{3} \\
\text { deformation }\end{array}$ \\
\hline & 1450 & 1458 & & & $1456(9)$ & $\begin{array}{c}v_{13}\left(b_{2}\right) \mathrm{CH}_{3} \\
\text { deformation }\end{array}$ \\
\hline & & & & & 1556 (f) & $\begin{array}{c}\nu_{8}\left(b_{1}\right) \mathrm{C}-\mathrm{O} \\
\text { stretching }\end{array}$ \\
\hline & & & $2696(1)$ & $2709(2)$ & & $\begin{array}{l}2 v_{2} \\
2 \nu_{2}\end{array}$ \\
\hline & & & $\begin{array}{l}2720(f) \\
2758(1) \\
2779(1)\end{array}$ & & & $\begin{array}{l}2 v_{3}-169 \\
3248-v_{5} \\
2 v_{3}-101\end{array}$ \\
\hline
\end{tabular}


Raman Spectra of Single Crystals of Zn \& Li Acetates Dihydrates 191

TABLE I (Contd.)

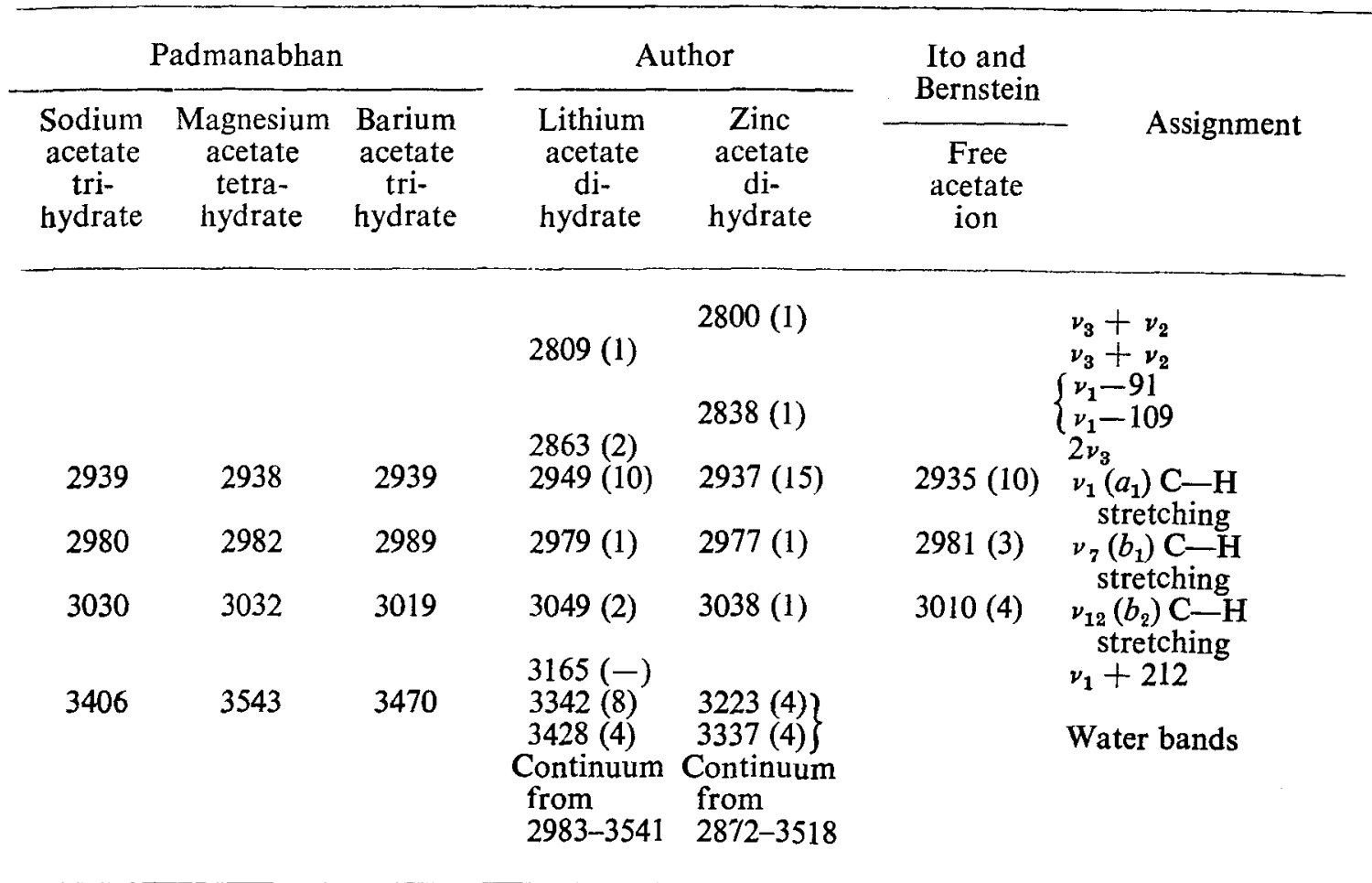

$f=$ feeble; * Mcasured from antistokes side.

ion. The assignments are given in the last column. The assignments closely follow those given by Ito and Bernstein (1956) for the free acetate ion.

\section{Structure Data}

Magnesium, sodium and barium acetates crystallise in monoclinic class. Their space groups and number of molecules in the unit cell are indicated against their formula below: $\mathrm{Mg}\left(\mathrm{CH}_{3} \mathrm{COO}\right)_{2} \cdot 4 \mathrm{H}_{2} \mathrm{O}\left(\mathrm{C}_{2 h}^{2}, 2\right)$; $\mathrm{NaCH}_{3} \mathrm{COO} .3 \mathrm{H}_{2} \mathrm{O}\left(\mathrm{C}^{3}{ }_{2 h}, 8\right)$ and $\mathrm{Ba}\left(\mathrm{CH}_{3} \mathrm{COO}\right)_{2} \cdot 3 \mathrm{H}_{2} \mathrm{O}\left(\mathrm{C}_{2 h}^{5}, 2\right)$. Details of the crystal structure for these three acetates are not available (Padmanabhan, 1948, 1952, 1953, 1954).

Zinc acetate dihydrate $\left[\mathrm{Zn}\left(\mathrm{CH}_{3} \mathrm{COO}\right)_{2} .2 \mathrm{H}_{2} \mathrm{O}\right]$ crystallises in the monoclinic class space group $\mathrm{C}^{6}{ }_{2 h}$ with four molecules in the unit cell, with the following unit cell dimensions: $a=14.50 \AA, b=5.32 \AA, c=11.02 \AA$ and $\beta=100^{\circ}$. The six nearest neighbours of a zinc atom are four oxygen atoms and two water molecules which form a badly distorted octahedron around the zinc atom. The following are the distances reported: $\mathrm{Zn}-\mathrm{O}_{(1)}$ 
$=2 \cdot 18, \mathrm{Zn}-\mathrm{O}_{(2)}=2 \cdot 17$ and $\mathrm{Zn}-\mathrm{H}_{2} \mathrm{O}=2 \cdot 14 \AA$. The formula units form extended columns parallel to the $b$-axis. Along such columns the units comprising them are firmly linked by hydrogen bonds of lengths $2 \cdot 49 \AA$. Such bonds exist between the two water molecules of one unit which are bonded respectively to the two oxygen atoms of the unit immediately above. Along the $c$-direction such bonds have lengths equal to $2 \cdot 74 \AA$.

Lithium acetate dihydrate $\left[\mathrm{LiCH}_{3} \mathrm{COO} \cdot 2 \mathrm{H}_{2} \mathrm{O}\right]$ crystallises in orthorhombic class space group $\mathrm{C}_{2} v^{11}$ with four formula units in the unit cell with the following unit cell dimensions : $a=6.86 \AA, b=11.49 \AA$ and $c=6.59 \AA$. The acetate ions are linked by weak hydrogen bonds to the water molecules having lengths $3.08 \AA$ and $3.14 \AA$ along the $a$-axis and along $c$ by the $c$-spacing. Along $b$ the nearest distance is $3.68 \AA$ and along $c 3.87 \AA$. Lithium is surrounded by six oxygens four of which belong to the acetate ions and the two other to the water molecules. The $\mathrm{Li}-\mathrm{O}$ and $\mathrm{Li}-\mathrm{H}_{2} \mathrm{O}$ linkages are reported to be $2 \cdot 27 \AA$ and $2.57 \AA$ long.

\section{Discussion}

Low Frequencies.-The low frequency spectra of these two acetates are quite complicated by the fact that lattice vibrations, low frequency vibrations of the hydrogen bonds and fundamental modes of the octahedral arrangements of oxygens and water molecules around the metal ions, all will be crowded in this region $\left(0-500 \mathrm{~cm}^{-1}\right)$ and overlap with one another.

The vibration spectrum of the hydrogen bonded $\mathrm{O}-\mathrm{O}$ linkage has been investigated both theoretically and experimentally by many workers. Gross and his co-workers (1957) have identified in the Raman spectra of simple substances like light and heavy ice, formic acid crystals, etc., frequencies of the hydrogen bond in the $\sim 150-300 \mathrm{~cm}^{-1}$ region. Reid (1959) had considered the stretching motions of $\mathrm{O}-\mathrm{H}$... $\mathrm{O}$ bonds as a function of the bonded distances. The theoretically calculated frequencies vary from $850 \mathrm{~cm}^{-1}$ for $\mathrm{O}-\mathrm{H} . . . \mathrm{O}$ distance of $2.43 \AA$ to about $110 \mathrm{~cm} .^{-1}$ for a distance of $2.74 \AA$. In zinc acetate dihydrate hydrogen bonds of lengths $2.49 \AA$ and $2.74 \AA$ are reported to be present, whereas very much weaker hydrogen bonds are present in lithium acetate dihydrate crystal. It is likely that the two intense diffuse lines at 80 and $91 \mathrm{~cm}^{-1}$ in zinc acetate dihydrate are due to the hydrogen bond vibrations. Gross (1957) had observed that when the $\mathrm{O}-\mathrm{H}$ vibrator is not excited, the vibrations of the hydrogen bond are defined by means of the potential curve with a very strong anharmonicity. The consideration of the vibrational energy levels of the hydrogen bond helps 
in explaining the presence of more than one hydrogen bond frequency. It is significant that there are no corresponding frequencies in the spectrum of lithium acetate dihydrate. However, frequencies in this region are present in the spectra of the other three acetates. In these cases data concerning the length of the hydrogen-bonded linkages are not available.

The vibrational spectra of the octahedral $\mathrm{MO}_{6}$ type complexes $(\mathrm{M}=$ metal atom) have been investigated by many workers (Eucken and Sauter, 1934; Lafont, 1959; Ananthanarayanan, 1961, 1962, 1962). These complexes belong to the point group $\mathrm{O}_{h}$ and have six normal vibrations designated as below: $\nu_{1}\left(\mathrm{~A}_{1 g}\right.$-totally symmetric $), \nu_{2}\left(\mathrm{E}_{g}\right.$-doubly degenerate $)$ and $\nu_{3}\left(\mathrm{~F}_{2 g}\right.$ triply degenerate) active in Raman effect only; $\nu_{4}\left(\mathrm{~F}_{2 u}\right), \nu_{5}, \nu_{6}\left(\mathrm{~F}_{1 u}\right)$ triply degenerate vibrations active in infra-red absorption only. The theoretical method of calculating the mean vibrational frequencies of such groups in crystals have been already dealt in the references quoted above and will not be repeated here. In the case of many magnesium and zinc sulphates where such octahedral $\mathrm{M}\left(\mathrm{OH}_{2}\right)_{6}$ ions are present the fundamental frequencies of these groups have been calculated and identified, where possible, experimentally (Lafont, 1959; Ananthanarayanan, 1962). The average values in wave numbers are for $\mathrm{ZnO}_{6}$ [393, 200, 276, 147, 275 and 378] and $\mathrm{MgO}_{6}$ [370, $205,251,133,268,499]$. It is interesting to note that excepting sodium acetate trihydrate the low frequency spectra extend considerably further up to $\sim 300-400 \mathrm{~cm} .^{-1}$ in all the other acetates. The $420 \mathrm{~cm} .^{-1}$ line in zinc acetate dihydrate may be assigned to the totally symmetric $\nu_{1}$ mode. The slight enhancement from the usual value of $393 \mathrm{~cm}^{-1}$ may be due to the differing crystalline field in the acetate compared to that found in the sulphates. The lines at 266 and $310 \mathrm{~cm} .^{-1}$ are the split components of the triply degenerate mode and that at $230 \mathrm{~cm}^{-1}$ the doubly degenerate mode. However polarisation studies may be useful in confirming these assignments. Details about the arrangement of water molecules and oxygens around the metal atoms in magnesium and barium acetates are not available. It is obvious that the frequencies in the $\sim 200-340 \mathrm{~cm}^{-1}$ in these two cases are due to the groups formed by oxygens and water molecules around the metal ions. In lithium acetate dihydrate the line at $237 \mathrm{~cm} .^{-1}$ may be assigned to the totally symmetric mode. This view is supported by an estimation of this frequency from the Badger's rule (1935) using the average of the reported $\mathrm{Li}-\mathrm{O}$ and $\mathrm{Li}-\mathrm{H}_{2} \mathrm{O}$ distances. It was also estimated by assuming $\nu_{1}=237 \mathrm{~cm} .^{-1}$ and employing the Eucken and Sauter's force field (1934) that the other two Raman active modes $\nu_{2}$ and $\nu_{3}$ will occur near $\sim 100$ and $\sim 180 \mathrm{~cm}^{-1}$ Since these will overlap with the lattice modes no attempt was made to identify them. 
Group theoretical analyses of the lattice spectra of zinc and lithium acetates have been worked out and are given in Tables II and III. Six translatory and six rotatory type of external modes in the former and nine translatory and twelve rotatory type modes of the latter are allowed by selection rules to appear in the Raman effect. The molecule is treated as one unit for these calculations. Only a much smaller number of external modes have been experimentally observed in all cases. There are common lattice lines with practically the same frequency shifts at $\sim 63$ and $\sim 107 \mathrm{~cm}^{-1}$ which are very intense. These may be attributed to the rotatory type of external oscillations of the acetate ion. Polarisation studies are essential to make definite assignments.

TABLE II

\begin{tabular}{lrrrrrrrrr}
\hline & & & & & & & \multicolumn{2}{c}{ Selection Rules } \\
\hline $\mathrm{C}^{\mathrm{s}}{ }_{2 h}$ & $\mathrm{E}$ & $\mathrm{C}_{2}$ & $i$ & $\sigma_{\mathrm{h}}$ & $\mathrm{T}$ & $\mathrm{T}^{\prime}$ & $\mathrm{R}^{\prime}$ & Raman Infra-red \\
\hline $\mathrm{A}_{1}$ & 1 & 1 & 1 & 1 & 0 & 3 & 3 & $\mathrm{p}$ & $\mathrm{f}$ \\
$\mathrm{A}_{2}$ & 1 & -1 & 1 & -1 & 0 & 3 & 3 & $\mathrm{p}$ & $\mathrm{f}$ \\
$\mathrm{B}_{1}$ & 1 & 1 & -1 & -1 & 1 & 2 & 3 & $\mathrm{f}$ & $\mathrm{p}$ \\
$\mathrm{B}_{2}$ & 1 & -1 & -1 & 1 & 2 & 1 & 3 & $\mathrm{f}$ & $\mathrm{p}$ \\
$\mathrm{U}_{\mathrm{R}}(\mathrm{S})$ & 4 & 0 & 0 & 0 & & & & & \\
$\mathrm{U}_{\mathrm{R}}(\mathrm{S}-v)$ & 4 & 0 & 0 & 0 & & & & & \\
$h_{\rho} \chi_{\rho}^{\prime}(\mathrm{T})$ & 3 & -1 & -3 & 1 & & & & & \\
$h_{\rho} \chi_{\rho}^{\prime}\left(\mathrm{T}^{\prime}\right)$ & 9 & 1 & 3 & -1 & & & & & \\
$h_{\rho} X_{\rho}^{\prime}\left(\mathrm{R}^{\prime}\right)$ & 12 & 0 & 0 & 0 & & & & & \\
\hline
\end{tabular}

$\mathrm{p}=$ permitted $\mathrm{f}=$ forbidden.

Internal Frequencies.-The fundamental vibrations of the acetate ion are distributed under the different symmetry types as below: $5 a_{1}+1 a_{2}$ $+5 b_{1}+4 b_{2}$. The torsional vibration about $\mathrm{C}-\mathrm{C}$ bond $\left(v_{6}\right)$ belonging to $a_{2}$ type is forbidden by selection rules to appear in the vibrational spectrum. All the remaining vibrations are active in both Raman effect and infra-red absorption. 
TABLE III

\begin{tabular}{|c|c|c|c|c|c|c|c|c|c|}
\hline \multirow{2}{*}{$\mathrm{C}_{2 v}{ }^{11}$} & \multirow{2}{*}{$\mathrm{E}$} & \multirow{2}{*}{$\mathrm{C}_{2}$} & \multirow{2}{*}{$\sigma_{v}$} & \multirow{2}{*}{$\sigma_{\bullet}^{\prime}$} & \multirow{2}{*}{$\mathbf{T}$} & \multirow{2}{*}{$\mathbf{T}^{\prime}$} & \multirow{2}{*}{$\mathbf{R}^{\prime}$} & \multicolumn{2}{|c|}{ Selection Rules } \\
\hline & & & & & & & & Raman & Infra-red \\
\hline$A_{1}$ & 1 & 1 & 1 & 1 & 1 & 2 & 3 & $\mathrm{p}$ & $\mathrm{p}$ \\
\hline $\mathrm{A}_{2}$ & 1 & 1 & -1 & -1 & 0 & 3 & 3 & $\mathrm{p}$ & $f$ \\
\hline $\mathbf{B}_{1}$ & 1 & -1 & 1 & -1 & 1 & 2 & 3 & $\mathbf{p}$ & $\mathbf{p}$ \\
\hline $\mathrm{B}_{\mathbf{2}}$ & 1 & -1 & -1 & 1 & 1 & 2 & 3 & $\mathbf{p}$ & $\mathbf{p}$ \\
\hline $\mathrm{U}_{\mathbf{z}}(\mathrm{S})$ & 4 & 0 & 0 & 0 & & & & & \\
\hline $\mathrm{U}_{2}(\mathrm{~S}-v)$ & 4 & 0 & 0 & 0 & & & & & \\
\hline$h_{p} x_{p}^{\prime}(\mathrm{T})$ & 3 & -1 & 1 & 1 & & & & & \\
\hline$h_{\rho} \chi_{\rho}^{\prime}\left(\mathrm{T}^{\prime}\right)$ & 9 & 1 & -1 & -1 & & & & & \\
\hline$h_{\rho} \chi_{\rho}^{\prime}\left(\mathrm{R}^{\prime}\right)$ & 12 & 0 & 0 & 0 & & & & & \\
\hline
\end{tabular}

It is noted that some of the fundamental modes of the free acetate ion are absent in the spectra of all these acetates. It is likely that the $\nu_{15}$ mode falls over either of the two mercury lines at $2576 \cdot 3 \AA$ and $2578 \cdot 4 \AA$ and escaped detection. Similarly the $\nu_{10}$ and $\nu_{8}$ modes might have been masked respectively by the mercury lines at $2603.2 \AA$ and $2639.9 \AA$. All these lines are too feeble to be recorded in the antistokes side.

The $\mathrm{C}-\mathrm{C}$ distances are reported to be $1.55 \AA$ in $\mathrm{LiCH}_{3} \mathrm{COO} .2 \mathrm{H}_{2} \mathrm{O}$ and $1.48 \AA$ in $\mathrm{Zn}\left(\mathrm{CH}_{3} \mathrm{COO}\right)_{2} \cdot 2 \mathrm{H}_{2} \mathrm{O}$. It is interesting to note that the $\mathrm{C}-\mathrm{C}$ stretching frequency is comparatively lowered in lithium acetate dihydrate which is to be expected on theoretical grounds. There are two sets of $\mathrm{C}-\mathrm{O}$ distances in these acetates being $1.22 \AA$ and $1.33 \AA$ long in lithium acetate and $1.33 \AA$ and $1.38 \AA$ long in zinc acetate. The $\nu_{3}(\mathrm{C}-\mathrm{O}$ stretching) and $\nu_{13}\left(\mathrm{CH}_{3}\right.$ deformation) frequencies of the free acetate ion are equally strong and occur close to one another $\left(1413\right.$ and $\left.1456 \mathrm{~cm}^{-1}\right)$. In both these acetates a very intense and broad band at $\sim 1450 \mathrm{~cm} .^{-1}$ alone is observed in this region. It is likely that these two modes merge together into the broad band at $\sim 1450 \mathrm{~cm}^{-1}$ These two modes are however clearly resolved in the spectra of magnesium and barium acetates. 
There are a number of extremely feeble lines in the spectra of these two acetates at $427,527, \sim 1250-1310$, and $\sim 2700-2870 \mathrm{~cm} .^{-1}$ which have been explained as overtones and combination frequencies (see Table I).

The lowering of the hydrogenic stretching frequency by hydrogen bond formation is well known and correlation table connecting $\mathbf{O}-\mathrm{H}$...O distances and $\mathrm{O}-\mathrm{H}$ frequencies is available (Nakamoto, Margoshes and Rundle, 1955). The considerably larger lowering of the $\mathrm{O}-\mathrm{H}$ frequencies in zinc acetate dihydrate is indicative of the presence of stronger hydrogen bonds. There is appreciable lowering of $\mathbf{O}-\mathbf{H}$ frequencies in the spectra of sodium and barium acetates.

\section{SUMMARY}

The Raman spectra of single crystals of zinc acetate dihydrate and lithium acetate dihydrate have been recorded for the first time. $\lambda 2537$ excitation has been used. Twenty-eight Raman frequency shifts in the spectrum of the former and twenty-seven in the latter have been recorded. Group theoretical analyses of the external modes of these acetates have been made and from intensity considerations the lines at $\sim 63$ and $107 \mathrm{~cm}^{-1}$ have been identified as the rotatory type of external oscillations of the acetate ion. The low frequency spectra which extend up to $\sim 400 \mathrm{~cm}^{-1}$ have been divided into three parts: external oscillations, low frequency hydrogen bond oscillations and vibrational frequencies of the octahedral arrangements of oxygens and water molecules around the metal ions. The internal frequencies are made up of acetate ion frequencies and water bands. Appropriate assignments have been given for all these observed Raman lines. Besides these a series of extremely feeble lines are present which have been explained as the octaves and combinations involving mainly the acetate frequencies and low frequency vibrations. A comparative study of the spectra of these two acetates with those of barium, magnesium and sodium acetates has also been made.

\section{ACKNOWLEDGEMENTS}

I thank Professor R. S. Krishnan for his interest in this work. My sincere thanks are also due to the Council of Scientific and Industrial Research for awarding me a Senior Research Fellowship.

\section{REFERENCES}

1. Amirthalingam, $V$. and Acta Cryst., 1958, 11, 896.

Padmanabhan, V. M.

2. Ananthanarayanan, V. .. Z. Physik, 1961, 163, 144; Ibid., 1962, 166, 318; "Vibrational Spectra of $\mathrm{M}\left(\mathrm{OH}_{2}\right)$, Complexes", 1962 (to be published). 
Raman Spectra of Single Crystals of Zn \& Li Acetates Dihydrates 197

3. Badger, R. M. $\quad$.. J. Chem. Phys., 1935, 3, 710.

4. Eucken, A. and Sauter, F. Z. Phys. Chem., 1934, Abt. B-26, 463.

5. Gross, E. F. $\quad$. Hydrogen Bonding by Hadzi, Pergamon Press, 1959, p. 203.

6. Ito, K. and Bernstein, H.J. Canad. J. Chem., 1956, 34, 170.

7. Lafont, R. ․ Ann. de Phys., 1959, 4, 905.

8. Nakamoto, K., Margoshes, J. Amer. Chem. Soc., 1955, 77, 6480.

K. M. and Rundle, R.E.

9. Padmanabhan, V. M. .. Proc. Ind. Acad. Sci., 1948, 21 A, 97; Curr. Sci., 1952, 21, 97; Proc. Ind. Acad. Sci., 1953, 37 A, 401; Ph.D. Thesis, Spectroscopic and $X$-ray Studies on Crystals, Bombay University, 1954.

10. Reid, C. ․ J. Chem. Phys., 1959, 30, 182.

11. Theimer, R. and Theimer, O. Mh. Chem., 1950, 81, 314.

12. Van Niekerk, J. N., Acta Cryst., 1953, 6, 720. Schoening, F. R. L. and

Talbot, J. H. 


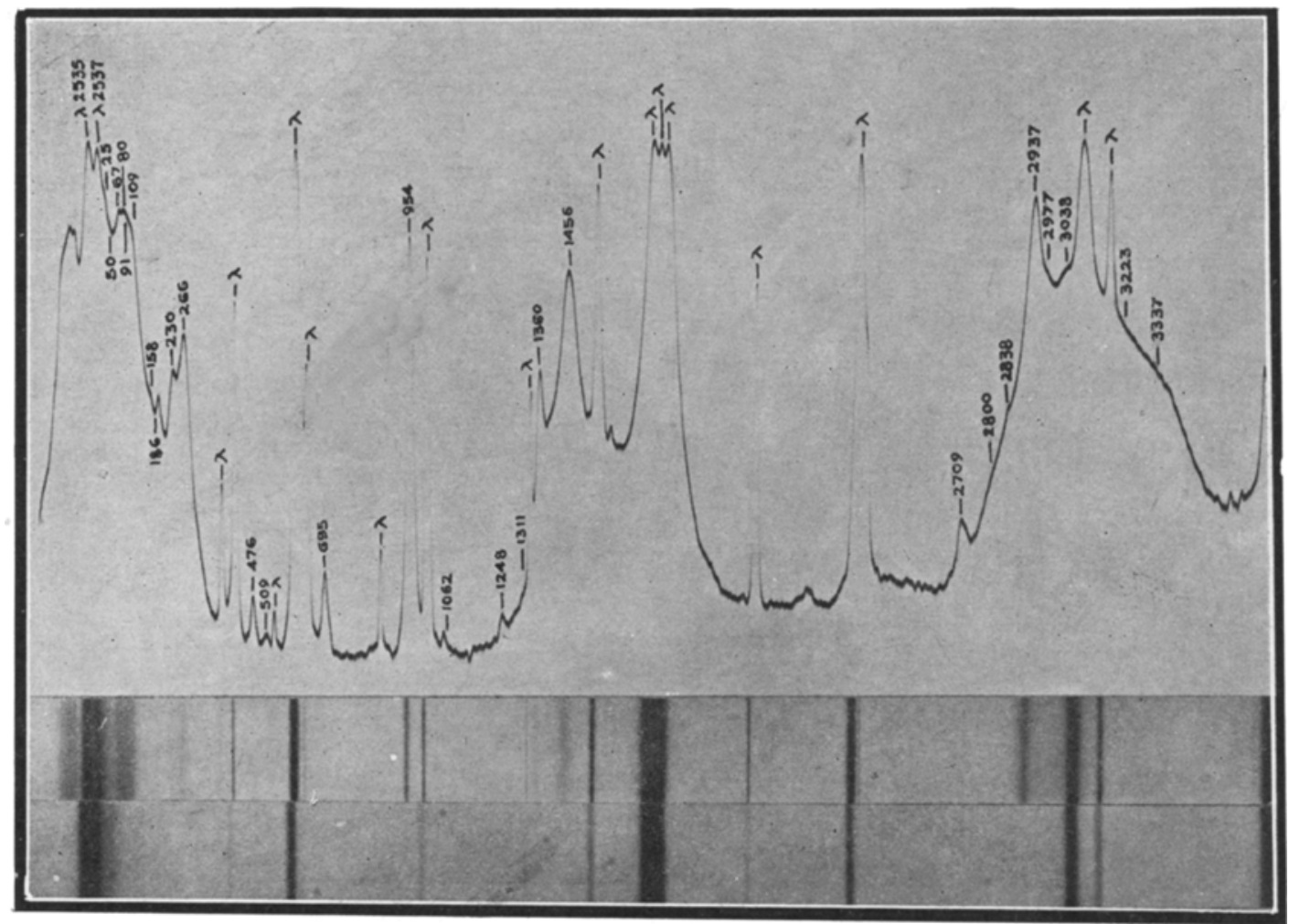

(a)

Fig. 1. (a) Microphotometer tracing of the Raman spectrum of zinc acetate dihydrate. (b) Raman spectrum. (c) Mercury spectrum. 


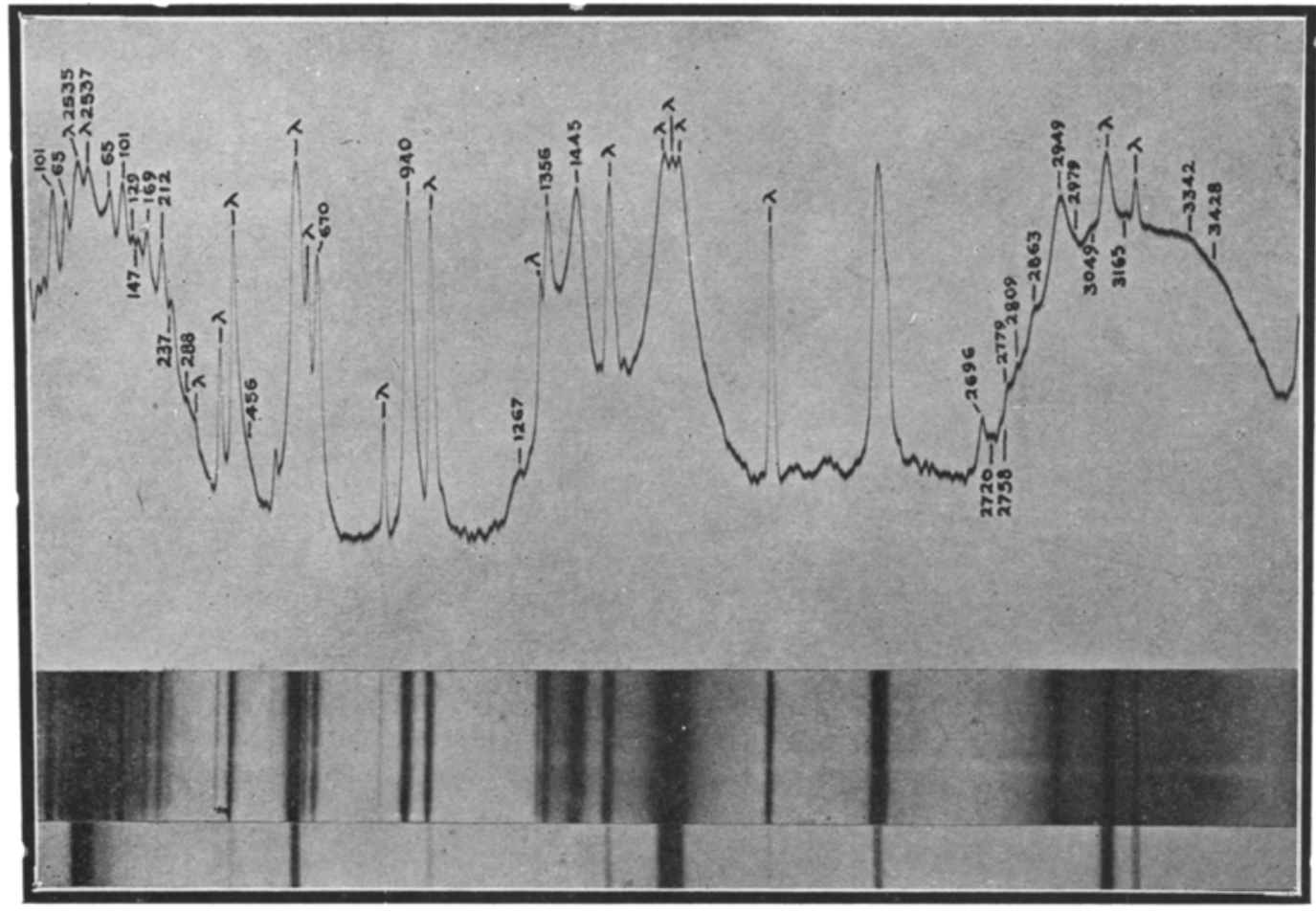

(a)

(b)

(c)

FIG. 2. (a) Microphotometer tracing of the Raman spectrum of lithium acetate dihydrate. (b) Raman spectrum. (c) Mercury spectrum. 